\title{
DAMPAK DEPRESIASI RUPIAH TERHADAP PERKEMBANGAN IMPOR INDONESIA
}

\author{
Amir Machmud \\ Fakultas Pendidikan Ekonomi dan Bisnis, Universitas Pendidikan \\ Indonesia Setia Budhi No 449 Bandung \\ Email: amir@upi.edu
}

\begin{abstract}
This study aims to identify and analyze the impact of depreciation on the development of Indonesian imports. The method used in this study was a descriptive study with data collection through observation to the data issued by Bank Indonesia (BI) during the fourth quarter of 2012 - the second quarter of 2015. The collected data were then analyzed by quadrant analysis through growth and share, as well as regression analysis. The results showed that the depreciation of the rupiah significantly negative effect on the development of imported goods in Indonesia, both consumer goods, raw and auxiliary materials, and capital goods. In other words, the higher the value, the exchange rate declining demand for imported goods as a whole.
\end{abstract}

Keywords: Rupiah Depreciation, Goods Imports, Growth and share Analysis

\section{PENDAHULUAN}

alam perdagangan internasional, kurs mata uang dapat dimaknai sebagai perbandingan nilai antar mata uang. Setiap negara pasti menginginkan nilai mata uangnya stabil terhadap mata uang negara lain, tak terkecuali Indonesia. Namun, untuk mencapai hal tersebut tidak semudah membalikkan telapak tangan karena kuat atau lemahnya nilai tukar mata uang tidak hanya ditentukan oleh kondisi dan kebijakan ekonomi di dalam negeri, tetapi juga kondisi perekonomian negara lain yang menjadi mitra dagangnya serta kondisi non-ekonomi seperti keamanan dan kondisi politik. 
Sederetan kerugian yang timbul akibat pelemahan rupiah diantaranya barang (komoditas) impor harganya akan semakin mahal. Akibatnya, cadangan devisa akan terkuras untuk membeli bahan baku industri. Sebab, masih banyak industri di dalam negeri yang masih mengandalkan bahan baku dari impor. Selain menguras cadangan devisa, pelemahan rupiah berpotensi kuat menimbulkan imported inflation (inflasi yang didorong oleh naiknya harga komoditas impor). Sebab, depresiasi rupiah terhadap valuta asing menyebabkan harga barang impor menjadi semakin mahal. Secara keseluruhan, dampak melemahnya nilai rupiah terhadap dolar AS ini lebih banyak negatifnya dibandingkan positifnya. Dalam teorinya, depresiasi menjadikan harga produk relatif lebih murah bagi negara lain dalam hal ini adalah impor.

Indonesia sebagai negara yang banyak mengimpor bahan baku industri mengalami dampak dari ketidakstabilan kurs ini, terutama importir yang dapat dilihat dari melonjaknya biaya produksi sehingga menyebabkan harga barang-barang milik Indonesia mengalami peningkatan. Dengan melemahnya rupiah menyebabkan perekonomian Indonesia menjadi goyah dan dilanda krisis ekonomi dan kepercayaan terhadap mata uang dalam negeri. Terjadinya depresiasi nilai tukar mendorong harga yang harus dibayar oleh masyarakat untuk memperoleh barang impormeningkat. Sehingga akan mendorong masyarakat mengurangi pembelian terhadap barang-barang impor. Bagi instansi, hal ini berpengaruh langsung kepada kemampuan membeli barang-barang modal seperti mesin-mesin dan alatalat industri lainnya, yang akhirnya dapat menurunkan kapasitas produksi dalam negeri.

Saat ini, terjadi fenomena kurs rupiah terhadap dolar USA yang berdampak pada perekonomian secara keseluruhan. Salah satunya adalah terhadap prkembangan impor barang-barang baik yang berhubungan dengan barang konsumsi, bahan baku dan penolong, serta barang-barang modal. Seperti diketahui bahwa industry di Indonesia masih bertumpu pada barang-barang impor, ini tentu akan berdampak pada keberlangsungan industry yang pada akhirnya akan berdampak pada tingkat kesejahteraan masyarakat Indonesia. Bukan hanya bahan baku dan barang modal, kecenderungan terhadap impor barang-barang konsumsi pun menunjukkan trend yang meningkat. Ini berarti Indonesiapun sangat ketergantungan terhadap barang konsumsi. Dengan adanya depresiasi 
rupiah, maka harga barang impor pun akan meningkat dan kondisi ini dapat berakibat fatal terhadap kesejahteraan masyaraka.

Fenomena depresiasi nilai rupiah terhadap dolar USA memang bukan hal yang baru dalam sejarah ekonomi Indonesia, tetapi yang menjadi perhatian dan fokus saat ini adalah nilai tukar rupiah terhadap dolar sudah mencapai angka yang tinggi. Selain nilai rupiah yang dianggap sudah tidak wajar, kurun waktu melemahnya pun patut diperhatikan. Kan fenomena tersebut, maka perlu adanya kajian tentang depresiasi rupiah dan perkembangan impor Indonesia. Kajian ini bertujuan untuk mengetahui dan menganalisis data yang berhuungan dengan variabel tingkat kurs dan impor, sehingga diperoleh gambaran tentang dampak depresiasi rupiah terhadap perkembangan barang-barang impor Indonesia.

Kurs mata uang dikenal sebagai nilai tukar yang merupakan rasio pertukaran antara Perubahan permintaan jumlah valuta asing mempengaruhi keseimbangan pasar valuta asing. Kondisi yang diperlukan untuk mencapai keseimbangan pasar valuta asing adalah interest parity condition yang merupakan suatu kondisi dimana imbalan yang diberikan masing-masing valuta asing, sehingga kepemilikan terhadap salah satu mata uang sama dengan kepemilikan terhadap mata uang yang lainnya.

Pada umumnya, jika keseimbangan di pasar valuta asing tidak seimbang, maka secara langsung akan mempengaruhi terhadap harga keseimbangan, hal tersebut dapat menyebabkan depresiasi atau apresiasi. Depresiasi merupakan penurunan nilai mata uang dalam negeri terhadap mata uang asing, sedangkan apresiasi merupakan peningkatan nilai mata uang domestik terhadap mata uang asing. Depresiasi menyebabkan harga barang ekspor bagi pihak luar negeri menjadi lebih murah dan impor bagi penduduk di dalam negeri menjadi lebih mahal. Sebaliknya bagi negara yang mengalami apresiasi mengakibatkan harga barang negara tersebut bagi pihak luar negeri semakin mahal, sedangkan harga impor bagi penduduk domestik menjadi lebih murah. Kurs keseimbangan sangat ditentukan oleh faktor-faktor yang dapat mempengaruhi terhadap permintaan dan penawaran valuta asing.

Ditinjau dari sudut aset, yaitu bahwa valuta asing diasumsikan sama dengan aset atau kekayaan lainnya, maka faktor yang mempengaruhi terhadap permintaan tersebut adalah tingkat imbalan yang diberikan, 
tingkat resiko dan tingkat likuiditas. Semakin tinggi tingkat imbalan yang diberikan, maka semakin tinggi permintaan akan valuta asing tersebut, dan sebaliknya. Tingkat imbalan yang diharapkan ini sangat tergantung pada tingkat bunga valuta asing tersebut. Ini berarti semakin tinggi tingkat suku bunga, maka semakin besar permintaan akan valuta asing tersebut, karena imbalan yang diberikan akan semakin besar. Dengan demikian, tampak bahwa tingkat bunga mempengaruhi permintaan terhadap valuta asing melalui tingkat imbalan yang diberikan.

Mata uang yang berbeda negara atau dengan kata lain kurs dapat diartikan sebagai harga satu unit mata uang asing dinyatakan dalam mata uang domestik. Secara lebih spesifik kurs ini ditunjukkan sebagai jumlah satuan mata uang domestik yang dipersiapkan oleh pembeli dan penjual untuk dipertukarkan dengan satu unit valuta asing. Valuta asing yang berarti pertukaran uang dari nilai mata uang yang berbeda. Valuta asing merupakan suatu mekanisme dimana orang dapat mentransfer daya beli antar negara, memperoleh atau menyediakan kredit untuk transaksi perdagangan internasional, dan meminimalkan kemungkinan resiko kerugian (exposure of risk) akibat terjadinya fluktuasi kurs mata uang. Pasar valuta asing menyediakan pasar sarana fisik maupun dalam pasar kelembagaan untuk melakukan perdagangan mata uang asing, menentukan nilai tukar mata uang asing dan menerapkan manajemen mata uang asing.

Dalam pasar valuta asing ditinjau dari sisi permintaan, jika harga valuta asing meningkat, maka permintaan terhadap valuta asing tersebut akan turun, dan sebaliknya jika harga valuta asing tersebut turun, maka permintaan akan valuta asing tersebut akan meningkat. Sedangkan ditinjau dari sisi penawaran, penawaran akan valuta asing akan meningkat apabila harga valuta asing meningkat, dan sebaliknya jika harga mengalami penurunan maka penawaran terhadap valuta asing tersebut akan menurun.

Ditinjau dari segi likuiditas, permintaan terhadap valuta asing memiliki hubungan yang positif, sama halnya dengan tingkat imbalan. Ini berarti semakin likuid maka semakin banyak permintaan akan valuta asing tersebut. Keadaan ini berbeda dengan dengan tingkat resiko yang memiliki hubungan yang negatif dengan permintaan akan valuta asing. Ini berarti 
semakin tinggi tingkat resiko terhadap valuta asing yang dimilikinya, maka semakin sedikit permintaan akan valuta asing tersebut.

Faktor yang mempengaruhi terhadap permintaan valuta asing adalah selera (dalam hal ini tidak terlepas dari imbalan, resiko dan likuiditas), harga mata uang tersebut (P\$), harga barang ekspor (Px), harga barang impor (PY), Pendapatan luar negeri (Y), tingkat suku bunga yang berlaku (I\$), dan pertumbuhan ekonomi (r). Secara matematik, hubungan antara variabelvariabel tersebut dapat dilukiskan dengan notasi berikut ini :

$\mathrm{Q} \$=\mathrm{f}(\mathrm{P} \$, \mathrm{Px}, \mathrm{Px}, \mathrm{PM}, \mathrm{Y}, \mathrm{I}$ \$, r).

Berdasarkan uraian sebelumnya, dalam kaitan antara depresiasi dengan kegiatan impor menunjukkan bahwa depresiasi mata uang domestik terhadap mata uang asing menyebabkan harga ekspor di luar negeri menjadi lebih murah, sedangkan harga impor di dalam negeri menjadi lebih mahal. Keadaan ini akan mendorong ekspor dan menekan terhadap impor. Dengan demikian akan mendorong neraca transaksi berjalan negara yang bersangkutan menjadi surplus yaitu ekspor lebih besar dari impor.

Kita sering melihat bahwa neraca transaksi berjalan suatu negara langsung memburuk begitu mata uangnya mengalami depresiasi, dan mulai membaik hanya dalam waktu beberapa bulan kemudian. Jika neraca transaksi berjalan mula-mula memburuk setelah terjadinya depresiasi, jalur pergerakannya akan menyerupai hurup "J". Bila diukur dalam output domestik, neraca perdagangan akan merosot tajam segera setelah terjadinya depresiasi mata uang secara riil, ini dikarenakan sebagian besar kontrak impor dan ekspor bersifat berjangka. Pada bulan-bulan pertama setelah depresiasi tersebut, volume impor dan ekspor mencerminkan keputusan pembelian yang didasarkan pada kurs riil yang lama, dan sebagaimana diketahui dampak pokok depresiasi adalah meningkatkan nilai kontrak impor berjangka. Jadi bila ekspor diukur dalam produk domestik tidak berubah, impor langsung melonjak bila diukur dalam produk domestik.

Sekalipun kontrak impor dan ekspor yang lama sudah semuanya terlaksana, masih diperlukan waktu beberapa lama bagi jadual pengapalan yang baru untuk menyesuaikan terhadap perubahan harga relatif tersebut. Pada sisi produksi, para produsen ekspor segera merasa perlu menambah jumlah pabrik, peralatan dan karyawannya. Bila impor umumnya terdiri 
dari materi setengah jadi, maka penyesuaian impor juga akan berlangsung secara bertahap karena para importir akan mencari teknik-teknik produksi baru yang lebih hemat dalam penggunaan materi setengah jadi yang harus diimpor itu. Disisni konsumsi juga terjadi keterlambatan. Secara grafik, kondisi ini digambarkan dengan bantuan kurva "J" pada Gambar 1.

Berdasarkan uraian tersebut di atas, tampak bahwa depresiasi efektif untuk mengatasi masalah defisit transaksi berjalan, karena dengan adanya depresiasi akan meningkatkan daya saing negara yang terkena depresiasi mata uangnya. Walaupun demikian, dalam kenyataannya depresiasi seringkali tidak efektif untuk mengatasi fenomena tersebut.

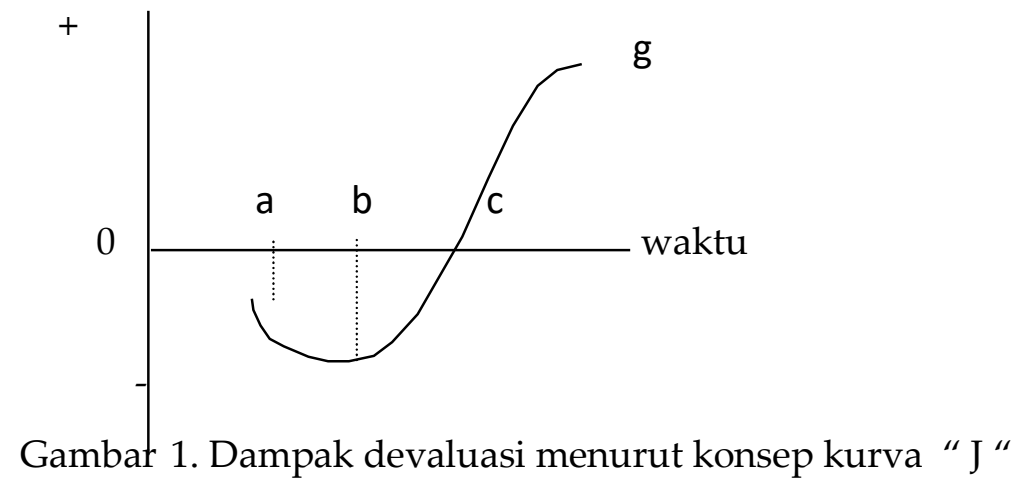

Salah satu pendekatan yang dapat digunakan untuk menjelaskan fenomena tersebut adalah pendekatan elastisitas, seperti yang dikemukakan oleh Marshal -Lerner bahwa penurunan nilai mata uang sangat tergantung pada kondisi elastisitas permintaan akan ekspor dan impor. Kondisi ini lebih dikenal dengan Marshall-lerner condition, yang menyatakan bahwa devaluasi akan efektif jika permintaan ekspor dan impor tersebut lebih besar daripada satu. Jika kurang dari satu maka penurunan nilai mata uang tidak akan memperbaiki terhadap transaksi berjalan.

Untuk melihat pengaruh devaluasi terhadap neraca perdagangan melalui pendekatan perhitungan elastistas, formula yang digunakan adalah sebagai berikut:

$\mathrm{Etb}, \mathrm{r}=(\mathrm{Vx} / \mathrm{VM}) \mathrm{X}\{[(\mathrm{dx}+1) /(\mathrm{dx} / \mathrm{sx})-1)]-[(\mathrm{sm}+1) /(\mathrm{sm} / \mathrm{dm})-1)]\}$

dimana:

$V x=$ Nilai ekspor 
$\mathrm{Vm}=$ Nilai impor

$\mathrm{dx}=$ Elastisitas permintaan ekspor

$\mathrm{dm}=$ Elastisitas permintaan impor

$\mathrm{sx}=$ Elastisitas penawaran ekspor

$\mathrm{sm}=$ Elastisitas penawaran impor

Etb,r = Elastisitas neraca perdagangan terhadap kurs.

Bila kita telaah dari formula di atas, maka pada dasarnya formula itu diturunkan dari tiga elastisitas. Ketiga elastisitas tersebut adalah elastisitas mata uang asing, elastisitas barang dan elastisitas devisa.

Berdasarkan uraian di atas, untuk menjelaskan dampak kurs terhadap perkembangan impor, maka dalam makalah ini digunakan pendekatan elastisitas permintaan impor. Impor diklasifikasikan ke dalam tiga kelompok menurut golongan barang ekonomi. Setiap golongan barang ekonomi ini kemudian diklasifikasikan ke dalam barang yang lebih spesifik. Masingmasing kelompok barang impor ini akan dihitung tingkat elastisitasnya. Untuk mengukur tingkat elastisitas ini digunakan model ekonometrika dengan meregres kurs terhadap impor. Secara matematik model tersebut dapat diformulasikan sebagai berikut :

$$
\mathrm{DX}=+\mathrm{K}
$$

Dimana Dx menunjukkan permintaan impor, menunjukkan konstanta, menunjukkan elastisitas, dan $\mathrm{K}$ menunjukkan kurs. Lebih lanjut, untuk menganalisis kondisi impor Indonesia, maka digunakan analisis pertumbuhan dan kontribusi (growth and share). Untuk mengukur pertumbuhan impor digunakan metode rata-rata dan metode bulanan. Selanjutnya, untuk mengetahui kecenderungan laju pertumbuhan ekonomi baik secara agregat maupun sektoral, digunakan analisis trend. Adapun metode yang digunakannya adalah trend linier dengan metode kuadrat terkecil, dimana persamaan yang digunakannya adalah sebagai berikut :

$$
Y \mathrm{i}=+\mathrm{xi}+
$$

dimana :

$$
\begin{aligned}
\text { Yi } & =\text { Nilai Impor } \\
& =\text { Intercept (nilai } \mathrm{Y} \text { apabila } \mathrm{x}=0 \text { ) } \\
& =\text { Slope atau arah kecondongan garis trend } \\
& =\text { Error term }
\end{aligned}
$$


$\mathrm{xi}=$ Time

Dari hasil perhitungan growth dan share tersebut di atas, selanjutnya akan digambarkan melalui analisis kuadran, yang menggambarkan tentang keadaan masing-masing impor. Dalam analisis kuadran ini, kita akan menyajikan scatter diagram. Pada diagram tersebut, sumbu horisontal menunjukkan rata-rata pertumbuhan impor sedangkan sumbu vertikal menunjukkan rata-rata share. Dengan membagi ke dalam empat diagram maka akan diperoleh gambaran masing-masing kuadran. Lebih jelas tentang analisis kuadran dapat digambarkan pada gambar berikut ini:

Share

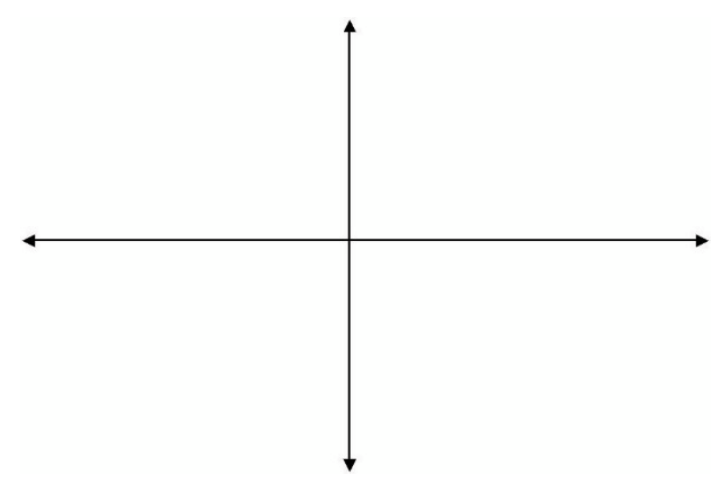

Growth

Gambar 2. Analisis Kuadran Yang Menggambarkan Hubungan Antara Pertumbuhan dan Peranan (Growth and share).

Kuadran I menunjukkan bahwa pertumbuhan impor komoditi tersebut di atas rata-rata, begitu pula dengan share (kontribusi) impor komoditi tersebut sangat besar. Keadaan ini menunjukkan bahwa seiring dengan berjalannya waktu, impor barang ini akan semakin besar begitu pula dengan peranannya. Kuadran I menunjukkan kondisi yang paling buruk, karena pada kuadran ini menunjukkan ketergantungan yang besar terhadap impor. Kuadran II, menunjukkan bahwa pertumbuhan impor tersebut di bawah rata-rata, sedangkan kontribusi atau share dari komoditi impor tersebut di atas rata-rata. Keadaan ini menggambarkan bahwa peranan atau kontribusi impor barang tersebut relatif besar, tetapi dalam pertumbuhannya relatif lambat. Keadaan ini memberikan indikasi pula bahwa seiring dengan berjalannya waktu akan memperkecil terhadap ketergantungan impor. Kuadran III merupakan kuadran yang paling ideal 
karena pertumbuhannya rendah dan ketergantungan terhadap impor tersebut juga rendah. Sedangkan kuadran IV memberikan gambaran bahwa pertumbuhan akan impor tersebut di atas rata-rata, tetapi kontribusi atau share dari komoditi tersebut relatif kecil. Keadaan ini memberikan indikasi bahwa seiring dengan berjalannya waktu menyebabkan ketergantungan akan impor akan semakin besar.

\section{HASIL DAN PEMBAHASAN}

Untuk menganalisis dampak depresiasi rupiah terhadap impor Indonesia, sebelumnya barang-barang impor dibedakan menurut golongan ekonomi yaitu barang modal, barang konsumsi, dan bahan baku. Lebih lanjut barang-barang tersebut diklasifikasikan kembali kepada komoditas barangbarang tersebut.

Dampak Depresiasi Rupaih Terhadap Perkembangan Impor Menurut Golongan Ekonomi

Berdasarkan pengelompokan barang ekonomi, selama kurun waktu September 2012 - Juli 2015 bahwa mayoritas impor Indonesia berupa bahan baku. Hal ini tampak dari share masing-masing barang menunjukkan untuk bahan baku rata-rata sebesar 69,11 persen, barang konsumsi sebesar 13,95 persen, dan barang modal sebesar 16,94 persen.

Jika dianalisis lebih jauh, adanya dominasi impor bahan baku dalam struktur impor Indonesia menunjukkan bahwa betapa besarnya ketergantungan sektor-sektor industri Indonesia terhadap bahan baku yang berasal dari impor. Ketergantungan semacam ini potensial menimbulkan kerawanan dadakan bagi industri di dalam negeri. Gejolak bahan baku yang bersangkutan di negara asalnya dengan mudah dan segera membangkitkan krisis pada industri yang bersangkutan. Jika keadaan ini terus berlangsung, maka mengakibatkan biaya produksi menjadi lebih besar, sehingga keunggulan untuk bersaing menjadi lemah, baik di dalam negeri maupun luar negeri.

Berdasarkan Tabel 1 tampak bahwa perkembangan impor Indonesia cenderung fluktuatif. pada akhir tahun 2014 terjadi penurunan nilai impor Indonesia. Ini disebabkan oleh nilai mata uang rupiah terdepresiasi terhadap dollar USA sepanjang tahun 2014. Impor barang bahan baku 
merupakan impor yang berkontribusi besar terhadap keseluruhan total impor menurut barang golongan ekonomi sedangkan barang konsumsi merupakan komoditas yang berkontribusi kecil terhadap total impor menurut barang golongan ekonomi. Seperti telah disebutkan dalam bagian kerangka pikir bahwa untuk mengetahui gambaran tentang hubungan antara laju pertumbuhan impor dengan share impor tersebut, maka digunakan analisis kuadran melalui scatter diagram berikut ini.

Tabel 1. Perkembangan Impor Indonesia Menurut Golongan Barag Ekonomi Pada Periode September 2012-Juli 2015.

\begin{tabular}{|c|c|c|c|c|c|c|}
\hline \multirow{2}{*}{ Bulan } & \multicolumn{2}{|c|}{ Barang Konsumsi } & \multicolumn{2}{|c|}{ Bahan Baku } & \multicolumn{2}{|c|}{ Barang Modal } \\
\hline & Growth & Growth & share & growth & share & \\
\hline 1 Sep 12 & $12 \%$ & $13 \%$ & $13 \%$ & $69 \%$ & $17 \%$ & $18 \%$ \\
\hline 01 Okt 2012 & $5 \%$ & $13 \%$ & $-9 \%$ & $69 \%$ & $-8 \%$ & $18 \%$ \\
\hline 1 Nov 12 & $-5 \%$ & $14 \%$ & $-6 \%$ & $68 \%$ & $4 \%$ & $18 \%$ \\
\hline 01 Des 12 & $0 \%$ & $14 \%$ & $6 \%$ & $66 \%$ & $-13 \%$ & $20 \%$ \\
\hline 01 Jan 13 & $2 \%$ & $14 \%$ & $-4 \%$ & $69 \%$ & $-3 \%$ & $17 \%$ \\
\hline 01 Feb 13 & $-6 \%$ & $15 \%$ & $1 \%$ & $68 \%$ & $-2 \%$ & $17 \%$ \\
\hline 01 Mar13 & $0 \%$ & $14 \%$ & $10 \%$ & $69 \%$ & $4 \%$ & $17 \%$ \\
\hline 1 Apr 13 & $8 \%$ & $13 \%$ & $0 \%$ & $71 \%$ & $5 \%$ & $16 \%$ \\
\hline 01 Mei 13 & $2 \%$ & $14 \%$ & $-7 \%$ & $70 \%$ & $-4 \%$ & $17 \%$ \\
\hline 01 Jun 13 & $15 \%$ & $15 \%$ & $11 \%$ & $68 \%$ & $15 \%$ & $17 \%$ \\
\hline $01 \mathrm{Jul} 13$ & $-19 \%$ & $15 \%$ & $-26 \%$ & $68 \%$ & $-30 \%$ & $17 \%$ \\
\hline 01 Ags 13 & $0 \%$ & $16 \%$ & $18 \%$ & $67 \%$ & $26 \%$ & $16 \%$ \\
\hline 1 Sep 13 & $-3 \%$ & $14 \%$ & $6 \%$ & $68 \%$ & $-5 \%$ & $17 \%$ \\
\hline 01 Okt 13 & $6 \%$ & $13 \%$ & $-8 \%$ & $71 \%$ & $1 \%$ & $16 \%$ \\
\hline 1 Nov 13 & $8 \%$ & $15 \%$ & $0 \%$ & $68 \%$ & $-6 \%$ & $17 \%$ \\
\hline 01 Des 13 & $-9 \%$ & $16 \%$ & $0 \%$ & $68 \%$ & $9 \%$ & $16 \%$ \\
\hline 01 Jan 14 & $-10 \%$ & $14 \%$ & $-7 \%$ & $68 \%$ & $-12 \%$ & $17 \%$ \\
\hline 01 Feb 14 & $15 \%$ & $14 \%$ & $0 \%$ & $69 \%$ & $-4 \%$ & $17 \%$ \\
\hline 01 Mar 14 & $-2 \%$ & $16 \%$ & $21 \%$ & $68 \%$ & $20 \%$ & $16 \%$ \\
\hline $1 \mathrm{Apr} 14$ & $0 \%$ & $13 \%$ & $-10 \%$ & $70 \%$ & $-1 \%$ & $16 \%$ \\
\hline 01 Mei 14 & $-3 \%$ & $14 \%$ & $7 \%$ & $68 \%$ & $-1 \%$ & $17 \%$ \\
\hline 01 Jun 14 & $-4 \%$ & $14 \%$ & $-12 \%$ & $70 \%$ & $-18 \%$ & $16 \%$ \\
\hline $01 \mathrm{Jul} 14$ & $17 \%$ & $15 \%$ & $3 \%$ & $70 \%$ & $16 \%$ & $15 \%$ \\
\hline 01 Ags 14 & $-3 \%$ & $16 \%$ & $7 \%$ & $67 \%$ & $6 \%$ & $17 \%$ \\
\hline 1 Sep 14 & $-3 \%$ & $15 \%$ & $-4 \%$ & $68 \%$ & $3 \%$ & $17 \%$ \\
\hline 01 Okt 14 & $-2 \%$ & $15 \%$ & $-8 \%$ & $67 \%$ & $-16 \%$ & $18 \%$ \\
\hline 1 Nov 14 & $-10 \%$ & $16 \%$ & $5 \%$ & $68 \%$ & $-3 \%$ & $16 \%$ \\
\hline 01 Des 14 & $-33 \%$ & $14 \%$ & $-11 \%$ & $70 \%$ & $1 \%$ & $16 \%$ \\
\hline 01 Jan 15 & $8 \%$ & $11 \%$ & $-6 \%$ & $71 \%$ & $-11 \%$ & $18 \%$ \\
\hline 01 Feb 15 & $19 \%$ & $12 \%$ & $5 \%$ & $71 \%$ & $20 \%$ & $17 \%$ \\
\hline 01 Mar 15 & $-3 \%$ & $13 \%$ & $2 \%$ & $68 \%$ & $-13 \%$ & $19 \%$ \\
\hline 1 Apr 15 & $1 \%$ & $13 \%$ & $-6 \%$ & $71 \%$ & $-4 \%$ & $16 \%$ \\
\hline
\end{tabular}




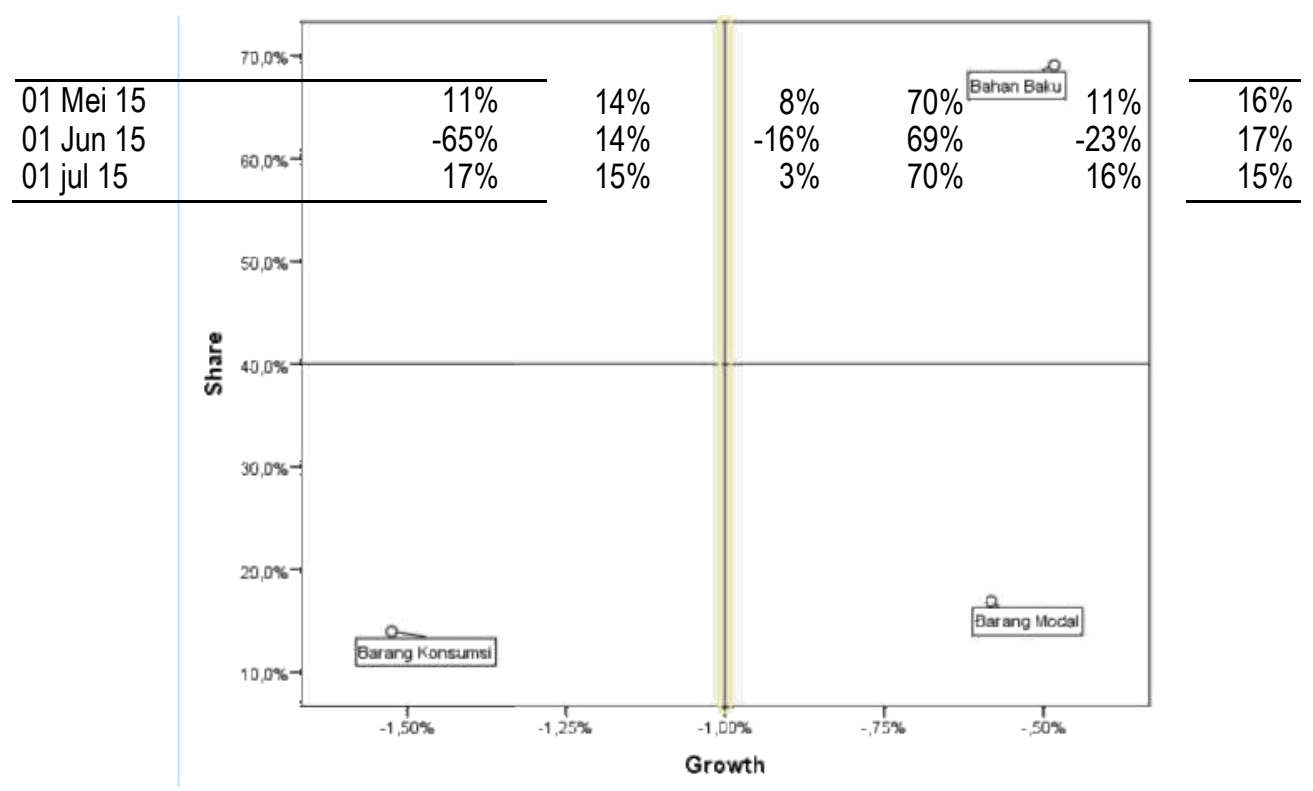

Gambar 3. Analisis Kuadran Impor Secara Keseluruhan Menurut Golongan Barang Ekonomi

Berdasarkan Gambar 3 tampak bahwa sektor bahan baku merupakan sektor dominan dari keseluruhan impor Indonesia sejak sepetember 2012 Juli 2015. Hal itu berdasarkan gambar kuadran di atas bahwa sektor bahan baku berada di kuadaran pertama yang diartikan sektor bahan baku

memiliki growth dan share yang tinggi atau di atas rata rata, ini menunjukan bahwa ketergantungan Indonesia terhadap bahan baku cukup besar kondisi tersebut menyebabkan Indonesia rentan terhadap krisis.

Ketergantungan yang tinggi terhadap impor bahan baku tersebut juga menutup peluang Indonesia untuk memperoleh keuntungan ketika terjadi depresiasi rupiah terhadap dollar. Berdasarkan data yang dirilis kementrian perdangangan nilai impor bahan baku Indonesia mengalami QE Journal | Vol.05 - No. 01 March 2016 - 38 
peningkatan dari tahun ke tahun pada tahun, pada tahun 2012 nilai impor bahan baku Indonesia sebesar 140.126,0 juta dollar meningkat pada tahun 2013 menjadi 141.957,9 juta dollar. Impor terbesar pada bahan baku adalah komoditas bahan baku olahan untuk industri, pada tahun 2014 nilai impor komoditi ini sebesar 57.171,7 juta dollar sedangkan impor terkecil adalah bahan baku komoditas Makanan dan minuman (Olahan) untuk Industri.

Berbeda dengan impor bahan baku, impor barang konsumsi berada di kuadran terbelakang atau kuadran tiga, hal ini menunjukan bahwa impor terhadap barang konsumsi memiliki growth dan share yang rendah atau di bawah rata rata. berdasarkan laporan yang dirilis kementrian perdangangan bahwa terdapat tren menurun pertumbuhan impor barang konsumsi, pada tahun 2013 nilai impor bahan konsumsi sebesar 13.138,9 juta dollar turun menjadi 12.667,2 juta dollar pada tahun 2014.

Tabel 2. Hasil Regresi Impor Secara Keseluruhan

\begin{tabular}{|c|c|c|c|c|}
\hline \multicolumn{5}{|c|}{$\begin{array}{l}\text { Dependent Variable: I } \\
\text { Method: Least Squares } \\
\text { Date: 10/07/15 Time: } 15: 13 \\
\text { Sample: 2012M09 2015M07 } \\
\text { Included observations: } 35\end{array}$} \\
\hline Variable & Coefficient & Std. Error & $\mathrm{t}$-Statistic & Prob. \\
\hline C & 25359423 & 1789623. & 14.17026 & 0.0000 \\
\hline$x$ & -950.3717 & 156.6088 & -6.068445 & 0.0000 \\
\hline R-squared & 0.527397 & \multicolumn{2}{|c|}{ Mean dependent var } & 14564759 \\
\hline Adjusted R-squared & 0.513076 & \multicolumn{2}{|c|}{ S.D. dependent var } & 1664739 \\
\hline S.E. of regression & 1161655. & \multicolumn{2}{|c|}{ Akaike info criterion } & 30.82403 \\
\hline Sum squared resid & $4.45 \mathrm{E}+13$ & \multicolumn{2}{|c|}{ Schwarz criterion } & 30.91291 \\
\hline Log likelihood & -537.4206 & \multicolumn{2}{|c|}{ Hannan-Quinn criter. } & 30.85471 \\
\hline F-statistic & 36.82602 & \multirow{2}{*}{\multicolumn{2}{|c|}{ Durbin-Watson stat }} & 1.651983 \\
\hline Prob(F-statistic) & 0.000001 & & & \\
\hline
\end{tabular}


Berdasarkan Tabel 2 terdapat pengaruh depresiasi rupiah terhadap impor ini tampak dari nilai $\mathrm{t}$ hitung barang $(6.068445)>$ nilai $\mathrm{t}$ table ( $\mathrm{T}$ kritis ) 1.697 maka Ho ditolak atau Ha artinya variable signifikan. Dan diketahui dengan probabilitas (p) sebesar 0.0000 lebih kecil dari alfa $(\alpha)=5 \%$ sehingga itu artinya signifikan karena kesalahan nya $0 \%$ dibawah ketentuan 5\%. Serta diketahui nilai R-Squared 0.527397 variabel depresiasi rupiah mempengaruhi sebesar 52,73 \% dan 47,27\% dipengaruhi oleh faktor lain diluar model.

Dampak Depresiasi Rupiah Terhadap Perkembangan Barang impor Konsumsi di Indonesia

Impor barang-barang konsumsi pada dasarnya meliputi barang-barang yang siap dipakai atau dikonsumsi tanpa harus melalui proses produksi terlebih dahulu. Barang-barang ini dapat diklasifikasikan ke dalam makanan dan minuman untuk rumah tangga, bahan bakar dan pelumas, alat angkutan bukan untuk industri, barang konsumsi yang tidak diklasifikasikan, dan barang lainnya. Untuk barang-barang konsumsi yang tidak diklasifikasikan dibedakan kembali kedalam tiga kelompok yaitu barang yang tahan lama, setengahan tahan lama, dan tidak tahan lama. Untuk melihat gambaran tentang dampak krisis moneter terhadap impor barang konsumsi di Indonesia dapat dilihat pada tabel 1.3.

Dari Tabel 3 tersebut, tampak bahwa impor barang konsumsi di Indonesia selama kurun waktu September 2012 - Juli 2015 didominasi oleh jenis barang angkutan bukan industri, sedangkan barang konsumsi tahan lama merupakan komoditi barang konsumsi yang paling sedikit untuk diimpor.

Jika diamati lebih jauh lagi dari Tabel .3 tampak pula bahwa penurunan impor barang konsumsi yang paling besar adalah pada komoditas alat angkutan bukan industri yaitu sebesar $-52 \%$. Keadaan ini memberikan indikasi bahwa permintaan akan kendaraan pribadi menurun karena adanya depresiasi rupiah. Jika dilihat dari nilai rata-rata pertumbuhan impor barang konsumsi selama kurun waktu September 2012 - Juli 2015 mengalami pertumbuhan rata-rata sebesar $11 \%$, tetapi pertumbuhannya cenderung tidak stabil atau mengalami fluktasi hal ini terlihat pada barang tahan lama pada bulan April mengalami peningkatan $24 \%$, tetapi pada bulan Mei mengalami penurunan sebesar $9 \%$, ketidakstabilan tersebut merupakan pengaruh dari depresiasi rupiah terhadap dollar. 
Seperti halnya impor menurut golongan barang ekonomi, maka untuk menggambarkan pertumbuhan dan share dari masing-masing barang konsumsi digunakan pula analisis kuadran. Berdasarkan plot pada Gambar 1.4, barang angkutan bukan industri menunjukkan kondisi yang paling buruk, dimana tingkat pertumbuhan dan ketergantungannya relatif besar. Hal ini dapat dimaklumi, karena industri dalam negeri tidak memproduksi angkutan bagi publik sehingga ketergantungan terhadap barang impor besar.

Tabel 3. Perkembangan Impor Barang-barang Konsumsi Indonesia Pada September 2012 - juli 2015

\begin{tabular}{llllll}
\hline Makanan dan Makanan dan & Alat & Barang & & & Barang yang \\
minuman, & angkutan & Barang & & Barang & Bahan bakar dan \\
baku, $\quad$ minuman, & Mobil & bukan untuk konsumsi & Konsumsi & $\begin{array}{l}\text { konsumsi } \\
\text { tidak }\end{array}$ & pelumas olahan, tidak dirinci
\end{tabular}

Bulan untuk rumah olahan, untuk Penumpang

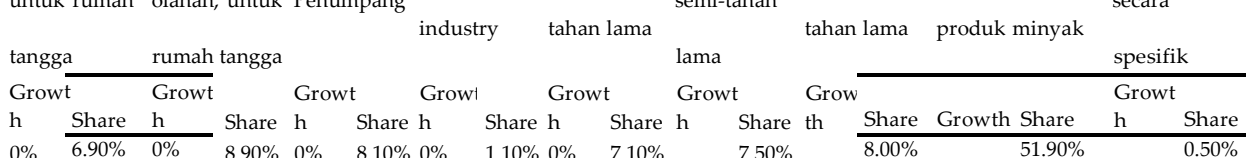

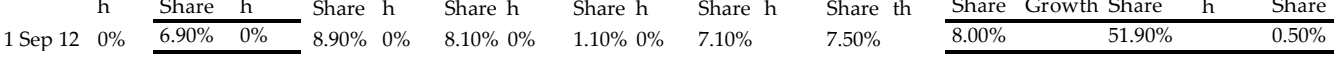

$\begin{array}{llllllllllllllllllllll}01 \text { Okt } & -43 \% & 3.50 \% & -9 \% & 7.30 \% & 1 \% & 7.30 \% & 8 \% & 1.10 \% & -4 \% & 6.10 \% & 13 \% & 7.60 \% & 12 \% & 8.00 \% & 23 \% & 57.40 \% & 273 \% & 1.70 \%\end{array}$

2012

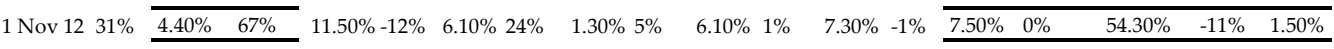

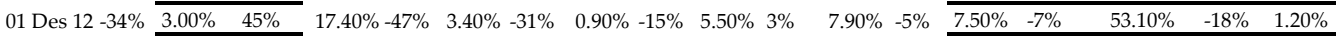
\begin{tabular}{lllllllllllllllllllllll}
01 & Jan 13 & $30 \%$ & $3.90 \%$ & $-65 \%$ & $6.10 \%$ & $33 \%$ & $4.50 \%$ & $-30 \%$ & $0.70 \%$ & $-2 \%$ & $5.30 \%$ & $9 \%$ & $8.60 \%$ & $-10 \%$ & $6.80 \%$ & $18 \%$ & $62.70 \%$ & $7 \%$ & $1.30 \%$ \\
\hline
\end{tabular} \begin{tabular}{llllllllllllllllllllll}
01 Feb $13-15 \%$ & $3.20 \%$ & $13 \%$ & $6.80 \%$ & $51 \%$ & $6.60 \%$ & $91 \%$ & $1.20 \%$ & $4 \%$ & $5.40 \%$ & $-20 \%$ & $6.70 \%$ & $15 \%$ & $7.60 \%$ & $-1 \%$ & $60.80 \%$ & $26 \%$ & $1.60 \%$ \\
\hline
\end{tabular}

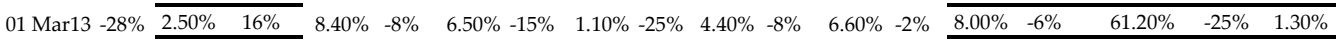

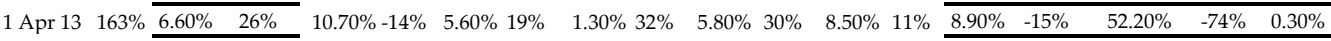

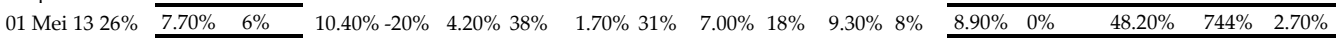

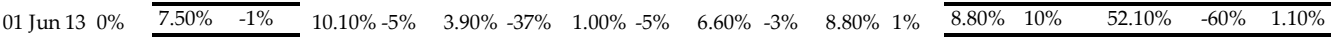

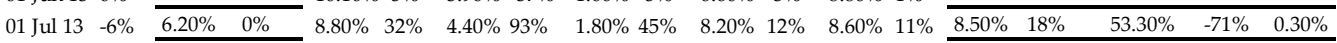
\begin{tabular}{llllllllllllllllllllllll}
01 Ags $13-31 \%$ & $5.30 \%$ & $-41 \%$ & $6.40 \%$ & $-16 \%$ & $4.60 \%$ & $-50 \%$ & $1.10 \%$ & $-50 \%$ & $5.10 \%$ & $-38 \%$ & $6.60 \%$ & $-38 \%$ & $6.50 \%$ & $-6 \%$ & $62.00 \%$ & $615 \%$ & $2.40 \%$ \\
\hline
\end{tabular}

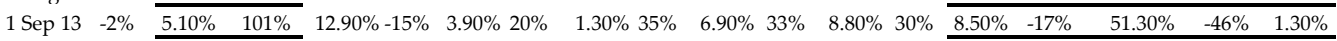

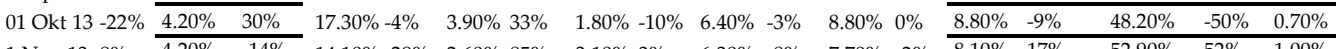

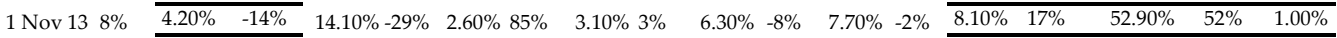
\begin{tabular}{llllllllllllllllllllll}
01 Des $1333 \%$ & $5.20 \%$ & $7 \%$ & $13.90 \%-24 \%$ & $1.90 \%$ & $-68 \%$ & $0.90 \%$ & $-20 \%$ & $4.60 \%$ & $-2 \%$ & $7.00 \%$ & $-9 \%$ & $6.80 \%$ & $9 \%$ & $53.60 \%$ & $575 \%$ & $6.00 \%$ \\
\hline
\end{tabular} \begin{tabular}{llllllllllllllllllll}
01 & Jan 14 & $-17 \%$ & $4.80 \%$ & $-51 \%$ & $7.50 \%$ & $34 \%$ & $2.70 \%$ & $-19 \%$ & $0.80 \%$ & $14 \%$ & $5.80 \%$ & $4 \%$ & $8.00 \%$ & $-3 \%$ & $7.30 \%$ & $2 \%$ & $59.80 \%$ & $-51 \%$ & $3.20 \%$ \\
\hline
\end{tabular} \begin{tabular}{lllllllllllllllllll}
$01 \mathrm{Feb} 14$ & $-1 \%$ & $5.30 \%$ & $6 \%$ & $8.90 \%$ & $55 \%$ & $4.70 \%$ & $52 \%$ & $1.40 \%$ & $-13 \%$ & $5.60 \%$ & $-18 \%$ & $7.30 \%$ & $-13 \%$ & $7.00 \%$ & $-12 \%$ & $59.10 \%$ & $-83 \%$ & $0.60 \%$ \\
\hline
\end{tabular}

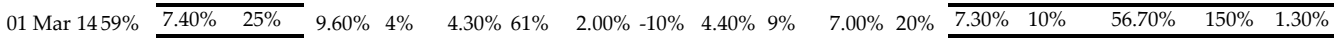

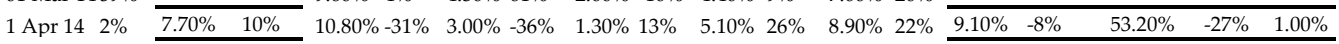

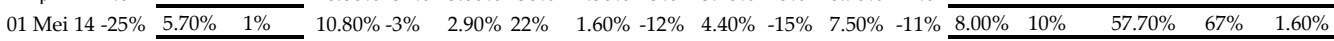

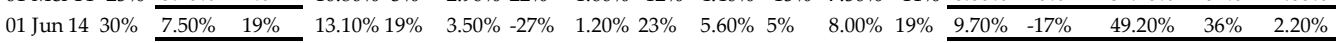
\begin{tabular}{llllllllllllllllllll}
$01 \mathrm{Jul} 14$ & $-39 \%$ & $4.70 \%$ & $-41 \%$ & $7.80 \%$ & $-20 \%$ & $2.80 \%$ & $-36 \%$ & $0.80 \%$ & $-22 \%$ & $4.40 \%$ & $-26 \%$ & $6.10 \%$ & $-26 \%$ & $7.30 \%$ & $22 \%$ & $60.90 \%$ & $128 \%$ & $5.20 \%$ \\
\hline
\end{tabular} \begin{tabular}{llllllllllllllllllll}
01 Ags 14 & $44 \%$ & $6.10 \%$ & $36 \%$ & $9.50 \%$ & $6 \%$ & $2.70 \%$ & $-17 \%$ & $0.60 \%$ & $7 \%$ & $4.30 \%$ & $14 \%$ & $6.20 \%$ & $15 \%$ & $7.50 \%$ & $-1 \%$ & $54.10 \%$ & $95 \%$ & $9.10 \%$ \\
\cline { 2 - 11 }
\end{tabular} \begin{tabular}{lllllllllllllllllllllll}
1 Sep 14 & $-5 \%$ & $5.80 \%$ & $6 \%$ & $10.40 \%$ & $14 \%$ & $3.10 \%$ & $3 \%$ & $0.60 \%$ & $42 \%$ & $6.20 \%$ & $8 \%$ & $6.80 \%$ & $14 \%$ & $8.70 \%$ & $0 \%$ & $55.10 \%$ & $-65 \%$ & $3.30 \%$ \\
\hline
\end{tabular}

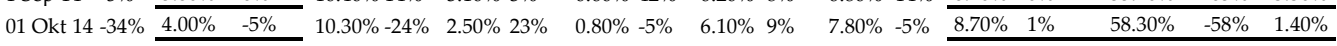

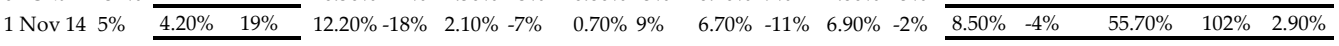

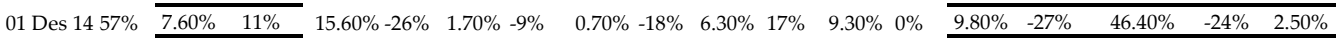

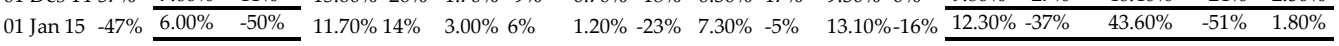

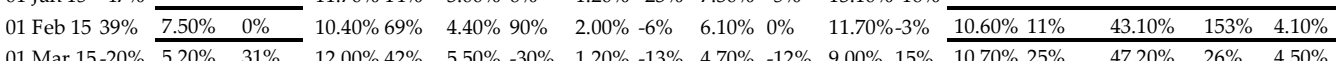

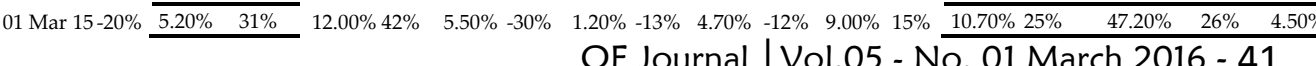




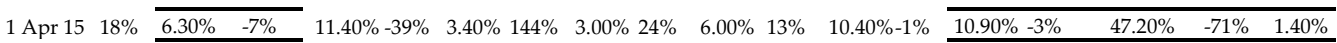

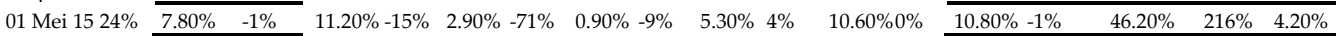




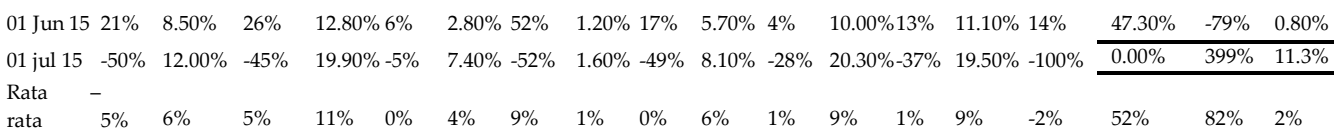

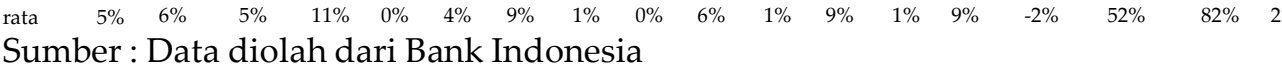

Berdasarkan Gambar 4, komoditas bahan bakar dan pelumas olahan produk minyak berada di kuadran dua yang menunjukan komoditas ini memiliki nilai share yang tinggi serta menunjukan bahwa komoditas ini merupakan komoditas yang memberikan kontribusi yang besar terhadap impor total barang konsumsi. Sedangkan komoditas barang konsumsi tahan lama, semi tahan lama, tidak tahan lama dan mobil penumpang merupakan komoditas yang berada di kuadran tiga yang menunjukan komoditas ini memiliki nilai growth dan share yang rendah atau dibawah rata-rata, kondisi ini secara ekonomi merupakan kondisi yang ideal karena ketergantungan komoditas ini terhdap produk impor kecil dibandingkan dengan komoditas bahan bakar yang memiliki ketergantungan tinggi terhadap produk impor.

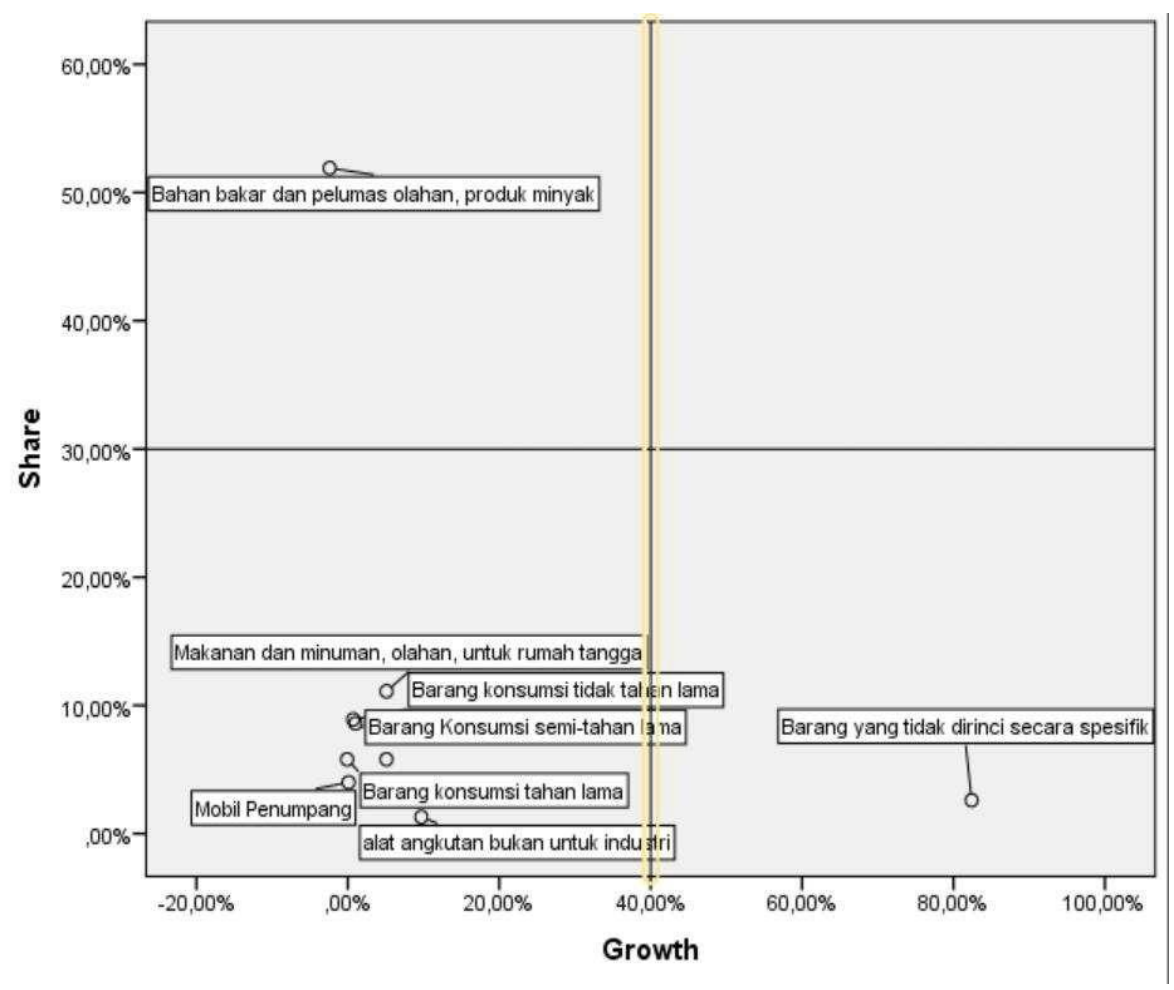

Gambar 4. Analisis Kuadran Impor Barang Konsumsi 
Berdasarkan Tabel 4 dapat disimpulkan terdapat pengaruh depresiasi rupiah terhadap impor ini dilihat dari nilai $t$ hitung barang konsumsi (17.31425) > nilai t table (T kritis) 1.697 maka Ho ditolak atau Ha artinya variable signifikan. Dan diketahui dengan probabilitas (p) sebesar 0.0002 lebih kecil dari alfa $(\alpha)=5 \%$ sehingga itu artinya signifikan karena kesalahan nya $0,2 \%$ dibawah ketentuan $5 \%$. Serta diketahui nilai R-Squared

0.344122 variabel depresiasi rupiah mempengaruhi sebesar $34.41 \%$ dan $66.59 \%$ dipengaruhi oleh faktor lain diluar model.

Tabel 4. Hasil Regresi Impor Barang Konsumsi

\begin{tabular}{|c|c|c|c|c|}
\hline \multicolumn{5}{|c|}{$\begin{array}{l}\text { Dependent Variable: } Y \\
\text { Method: Least Squares } \\
\text { Date: } 10 / 06 / 15 \text { Time: } 15: 02 \\
\text { Sample: } 2012 \text { M092015M07 } \\
\text { Included observations: } 35\end{array}$} \\
\hline Variable & Coefficient & Std. Error & t-Statistic & Prob. \\
\hline c & 3969384 & 465475.8 & 8.527583 & 0.0000 \\
\hline$x$ & -169.4936 & 40.73349 & -4.161039 & 0.0002 \\
\hline $\begin{array}{l}\text { R-squared } \\
\text { Adjusted R-squared } 0\end{array}$ & $\begin{array}{l}0.344122 \\
.324247\end{array}$ & \multicolumn{2}{|c|}{$\begin{array}{l}\text { Mean dependent var } \\
\text { S.D. dependent var }\end{array}$} & $\begin{array}{l}2044214 . \\
367551.8\end{array}$ \\
\hline S.E. of regression & 302143.0 & \multicolumn{2}{|c|}{ Akaike info criterion } & 28.13063 \\
\hline Sum squared resid & $3.01 \mathrm{E}+12$ & \multicolumn{2}{|c|}{ Schwarz criterion } & 28.21951 \\
\hline Log likelihood & -490.2861 & \multirow{2}{*}{\multicolumn{2}{|c|}{$\begin{array}{l}\text { Hannan-Quinn criter. } \\
\text { Durbin-Watson stat }\end{array}$}} & 28.16131 \\
\hline F-statistic & 17.31425 & & & 0.941110 \\
\hline Prob(F-statistic) & 0.000213 & \multicolumn{2}{|c|}{ Durbin-Watson stat } & \\
\hline
\end{tabular}

Sumber: Hasil Pengolahan

Dampak Depresiasi Rupiah Terhadap Perkembangan Impor Bahan Baku dan Penolong di Indonesia

Impor bahan baku dan penolong ini diklasifikasikan ke dalam bahan makan dan minuman untuk industri, bahan baku untuk industri, pelumas dan bahan bakar, suku cadang dan perlengkaannya dibagi menjadi barang modal dan alat angkutan.

Berdasarkan hasil pengolahan data yang dikeluarkan Bank Indonesia tampak bahwa selama kurun waktu September 2012 - Juli 2015 
menunjukkan impor yang paling banyak didominasi oleh impor bahan baku. Keadaan ini memberikan indikasi bahwa industri-industri di Indonesia masih ketergantungan terhadap barang impor. Keadaan ini sangat membahayakan apabila terjadi ketidakstabilan harga bahan baku.

Tabel 5 menggambarkan tentang rata-rata pertumbuhan impor bahan baku selama kurun waktu September 2012 - Juli 2015 menunjukkan pertumbuhan yang positif yaitu sebesar $9.85 \%$, tetapi secara keseluruhan impor bahan baku mengalami penurunan. Penurunan yang paling dratis terjadi pada impor pelumas dan bahan bakar, penurunan tersebut sebesar 99\% pada bulan Juli. Lebih lanjut untuk menggambarkan hubungan antara pertumbuhan dan share dari setiap barang, maka dilakukan analisis kuadran, seperti tampak pada Gambar 3 berikut ini.

Tabel 5. Perkembangan Nilai Impor Bahan Baku Indonesia pada Bulan September 2012 hingga Juli 2015

\begin{tabular}{|c|c|c|c|c|c|c|c|c|c|c|c|c|c|c|c|c|}
\hline \multirow[t]{2}{*}{ Bulan } & \multicolumn{2}{|c|}{$\begin{array}{c}\text { Makanan \& } \\
\text { Minuman, Baku } \\
\text { Untul Industri }\end{array}$} & \multicolumn{2}{|c|}{$\begin{array}{c}\text { Makanan \& } \\
\text { Minnman, } \\
\text { Olahan Untuk } \\
\text { Industri }\end{array}$} & \multicolumn{2}{|c|}{$\begin{array}{c}\text { Bahan Pasolkan, } \\
\text { Baku Untulk } \\
\text { Industri }\end{array}$} & \multicolumn{2}{|c|}{$\begin{array}{c}\text { Bahnen Pasok } 2 \text { n } \\
\text { Olahan Untuk } \\
\text { Industri }\end{array}$} & \multicolumn{2}{|c|}{$\begin{array}{l}\text { Suku Cadang } \\
\text { Barang Modal }\end{array}$} & \multicolumn{2}{|c|}{$\begin{array}{c}\text { Suku Cadang } \\
\text { Alat Angkutan }\end{array}$} & \multicolumn{2}{|c|}{$\begin{array}{l}\text { Bahan Bakar Dan } \\
\text { Pelumas Baku }\end{array}$} & \multicolumn{2}{|c|}{$\begin{array}{l}\text { Bahan Bakar Dan } \\
\text { Pelumas, Olahan }\end{array}$} \\
\hline & Grencth & Share & Grentith & Share & Grentet & Share & Grenth & Shave & Grenth & Shave & Grencth & Shave & Grencth & Share & \begin{tabular}{l|l} 
Grenth \\
\end{tabular} & Shave \\
\hline $1 \operatorname{Sep} 12$ & & 3\%: & & 28 & & 48 & & $45 \%$ & & 158 & & $7 \%$ & & 98 & & $14 \%$ \\
\hline 10 kt 2012 & 199 & 40 & $46 \mathrm{~s}$ & 39 & 60 & 40 & 38 & 439 & 11 尔 & 148 & 14 2 & $7 \%$ & 308 & 11\% & 12 \% & $14 \%$ \\
\hline 1 Nov 12 & -169 & 38 & -39 & 39 & 2 和 & 5 刍 & $-2 \%$ & $46 \%$ & -189 & 139 & -12 a & $6 \%$ & -478 & 68 & 78 & $17 \%$ \\
\hline 1 Des 12 & -219 & $3 \%$ & -118 & 38 & -6 乎 & $5 \%$ & $-13 \%$ & 439 & 158 & 168 & -64 & $6 \%$ & 198 & S年 & -9 \% & $16 \%$ \\
\hline $1 \operatorname{Tan} 13$ & -48 & $3 \%$ & 79 & 39 & 248 & 59 & $3 \%$ & 448 & -69 & 148 & 98 & $7 \%$ & 378 & $10 \%$ & -78 & $14 \%$ \\
\hline 1 Feb 19 & -148 & 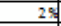 & $-21 \mathrm{~d}$ & 28 & -11 年 & 50 & 08 & $46 \%$ & -79 & 148 & 198 & $8 \%$ & -258 & 8s & -1 争 & $15 \%$ \\
\hline 1 Mar13 & 15 & $3 \approx$ & 28 & 28 & -17 \& & 48 & -39 & 448 & $-2 \pi$ & 139 & -248 & $6 \%$ & 758 & 148 & -5 亦 & 148 \\
\hline $1 \mathrm{Apr} 13$ & 789 & 48 & 208 & 32 & $31 \%$ & 50 & $19 \%$ & $47 \%$ & $10 \mathrm{a}$ & 139 & 278 & $7 \%$ & -78 & 12\% & $-91 \%$ & 98 \\
\hline 1 Mei 13 & -19 & 48 & 18 & 39 & -2 a & 58 & 0 : & 478 & 38 & 138 & 98 & $8 \%$ & -279 & 98 & $29 \%$ & $11 \%$ \\
\hline 1 Tun 13 & -219 & 48 & 698 & 58 & 10 & 50 & $-17 \%$ & $42 \%$ & -19 & 148 & -27 & $6 \%$ & -58 & 98 & $26 \%$ & $15 \%$ \\
\hline 1 Tul 13 & 178 & 48 & -519 & 28 & 10. & 5 年 & $21 \%$ & $46 \%$ & -48 & 128 & 268 & $7 \%$ & 198 & 98 & 11\% & $15 \%$ \\
\hline $1 \mathrm{~A}=\mathrm{13}$ & -269 & $4 \%$ & $-2 \pi$ & 38 & $-30 \%$ & 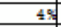 & $-33 \%$ & 419 & -248 & 138 & -25 S & $7 \%$ & 108 & 14 知 & $-29 \%$ & $15 \%$ \\
\hline 1 Sep 13 & -369 & 28 & -159 & 28 & 34\% & $5 \%$ & $28 \%$ & 448 & 958 & 148 & 27 \% & $8 \%$ & 48 & 12 的 & 3ब & $19 \%$ \\
\hline 10 oht 19 & 105 & 48 & -30 & 29 & 90 & 58 & 78 & $45 \%$ & 09 & 148 & $19 \mathrm{~g}$ & $8 \%$ & -208 & $9:$ & $10 \%$ & $19 \%$ \\
\hline 1 Nov 19 & -119 & 4 क्ष & 39 & 28 & -10 \% & 5 尔 & -148 & $42 \%$ & -69 & 148 & -27 9 & $6 \%$ & 128 & 11 बे & 119 & $16 \%$ \\
\hline $1 \mathrm{Des} 13$ & 19 & 48 & $-12 \mathrm{~s}$ & 28 & -7 和 & 5 : & 28 & 439 & -48 & 139 & 00 & $6 \%$ & -118 & $10 \%$ & 11\% & $18 \%$ \\
\hline $1 \operatorname{Tan} 14$ & -11 s & $3:$ & 309 & 28 & -2 秘 & 5\% & 68 & $45 \%$ & 18 & 139 & -68 & $6 \%$ & 238 & $12 \mathrm{~s}$ & -288 & $13 \%$ \\
\hline 1 Feb 14 & 93 & 48 & 128 & 39 & -139 & 42 & $-10 \%$ & 448 & -148 & 129 & 89 & $7 \%$ & -248 & $10 \%$ & 148 & $16 \%$ \\
\hline $1 \mathrm{Mar} 14$ & 39. & 48 & $21 \mathrm{9}$ & 48 & 14 \% & 50 & $0 \%$ & 448 & so & 198 & -149 & $6 \%$ & 158 & 110 & $-15 \%$ & $13 \%$ \\
\hline 1 Apr 14 & 458 & $5 \%$ & -28 & 38 & 19 \% & 5\% & $25 \%$ & 458 & 15 s & 139 & 19 孚 & $6 \%$ & 408 & $13 \%$ & -18 & $11 \%$ \\
\hline 1 Mei 14 & -139 & 5\% & -9 艛 & 32 & -3 : & 5\% & $-11 \%$ & $45 \%$ & -16 \% & 128 & -239 & $5 \%$ & -208 & 12 年 & $17 \%$ & $14 \%$ \\
\hline \begin{tabular}{|l|l|} 
Tun 14 \\
\end{tabular} & 39 & $5 \%$ & $26 \mathrm{9}$ & 38 & -1 舟 & $5 \%$ & $13 \%$ & 479 & 98 & 128 & 310 & $6 \%$ & -10 & 110 & $-17 \%$ & $11 \%$ \\
\hline 1 Tul 14 & -205 & 42 & -498 & 28 & $-35 \%$ & 48 & $-17 \%$ & $45 \%$ & -108 & 198 & -239 & $5 \%$ & 108 & $13 \%$ & $10 \%$ & 148 \\
\hline 1 A $=: 14$ & -58 & 40 & 258 & 39 & $36 \%$ & 5 年 & 52 & $47 \%$ & $12 \mathrm{~s}$ & 148 & 148 & $6 \%$ & -228 & $10 \%$ & $-11 \%$ & $12 \%$ \\
\hline 1 Sep 14 & 39 & 48 & $17 \mathrm{a}$ & 38 & 290 & 60 & 68 & $47 \%$ & -19 & 139 & 59 & $6 \%$ & -68 & $9 \%$ & 218 & $19 \%$ \\
\hline 10 kt 14 & 69 & 48 & $-28 \mathrm{~s}$ & 28 & -11 告 & 5 年 & $-1 \%$ & $43 \%$ & -10 & 139 & -59 & $6 \%$ & -239 & 7 艉 & 3\% & $14 \%$ \\
\hline 1 Nov 14 & -278 & $3 \%$ & -169 & 28 & -11 \% & 5 ? & $-7 \%$ & 498 & -39 & 198 & -39 & $6 \%$ & 178 & 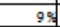 & -218 & $12 \%$ \\
\hline 1 De: 14 & 345 & 4 皮 & -48 & 28 & $13 \%$ & 6\% & 5\% & 498 & 48 & 139 & -79 & $5 \%$ & -39 & 98 & $9 \%$ & $13 \%$ \\
\hline $1 \operatorname{Tan} 15$ & -229 & 48: & 678 & 39 & -5 s & $6 \%$ & $-9 \%$ & $53 \%$ & -92 & 148 & -12 & $6 \%$ & -368 & $6 \%$ & -498 & $8 \%$ \\
\hline 1 Feb 15 & 208 & 5 尔 & -238 & 39 & -15 乎 & 5 年 & $-7 \%$ & $52 \%$ & -79 & 148 & 39 & $7 \%$ & 78 & 7 秘 & $-15 \%$ & $7 \%$ \\
\hline 1 Mar 15 & -58 & 48 & -79 & 39 & 9 乎 & 5 蛋 & $0 \%$ & $50 \%$ & 48 & 148 & -39 & $6 \%$ & 539 & 10 s & $16 \%$ & $8 \%$ \\
\hline 1 Apr 15 & 285 & $5 \%$ & $10 \mathrm{~s}$ & 39 & $-3 \%$ & 5 争 & 28 & $50 \%$ & 78 & 148 & 19 & $6 \%$ & -179 & sq & $3 \%$ & $8 \%$ \\
\hline $1 \mathrm{Mei} 15$ & -255 & 48 & 98 & 32 & -12 A & $5 \%$ & $-3 \%$ & 498 & -69 & 148 & -189 & $5 \%$ & 32 & 98 & $20 \%$ & $10 \%$ \\
\hline 1 Tun 15 & 79 & 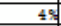 & -29 & 39 & -5 乎 & 4 的 & $3 \%$ & 498 & $19 \mathrm{~d}$ & 158 & 200 & $6 \%$ & 308 & 11\% & $-12 \mathrm{~s}$ & $9 \%$ \\
\hline 1 jul 15 & -948 & $3 \%$ & -498 & 18 & -92 \& & 32 & $22 \%$ & 588 & -248 & 118 & 89 & $6 \%$ & 478 & $16 \%$ & $-37 \%$ & 18 \\
\hline
\end{tabular}

Sumber: Bank Indonesia (data diolah)

Berdasarkan Gambar 5, komoditas bahan pasokan olahan untuk industry berada pada kuadran satu yang menunjukan bahwa komoditas ini memiliki growth dan share yang tinggi atau di atas rata rata ini selaras 
dengan laporan kementrian perdangangan yang menunjukan pada tahun 2014 nilai impor bagan pasokan olahan untuk industry memiliki nilai terbesar dari pada komoditas impor bahan baku lain nya yaitu sebesar $57.171,7$ juta dollar.

Berbeda dengan $\mathrm{n}$ impor komoditas bahan bakar dan pelumas, suku cadang barang modal, suku cadang alat angkutan dan bahan pasokan baku untuk inudstri berada di kuadran tiga yang menunjukan komoditas ini berada dikuadran terbelakang dengan nilai growth dan share dibawah ratarata atau rendah.hal ini seleras dengan laporan BPS bahwa komoditas suku cadang alat angkutan mengalami penurunan dari tahun 2013 - 2014, pada tahun 2013 nilai impor komoditas ini sebesar 16.803,3 juta dollar sedangkan pada tahun 2014 nilai impor nya sebesar 15.679,3 juta dollar.

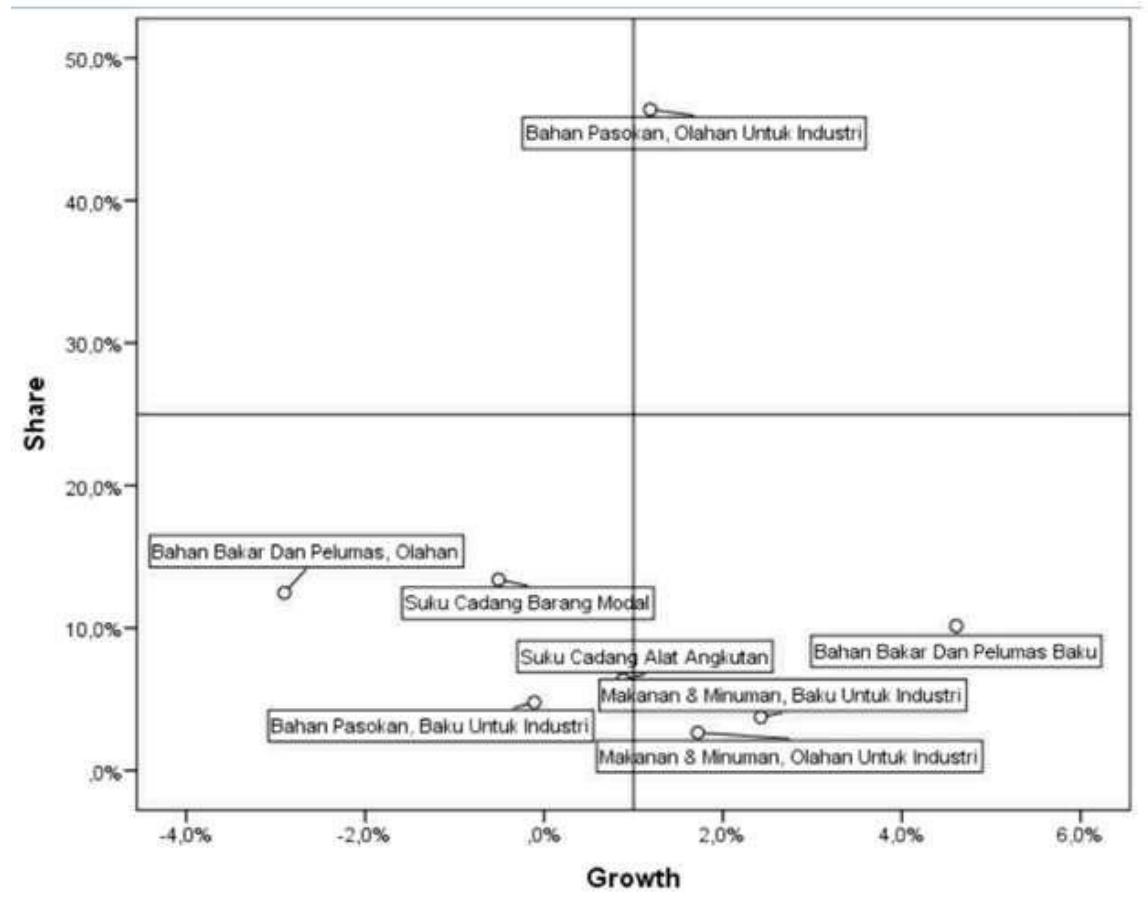

Gambar 5. Analisis Kuadran Impor Bahan Baku

Berdasarkan Tabel 6 dapat disimpulkan terdapat pengaruh depresiasi rupiah terhadap impor bahan baku itu tampak dari nilai thitung barang bahan baku (5.726828) > nilai $\mathrm{t}$ table ( $\mathrm{T}$ kritis ) 1.697 maka Ho ditolak atau Ha artinya variable signifikan. Dan diketahui dengan probabilitas (p) sebesar 0.0000 lebih kecil dari alfa $(\alpha)=5 \%$, sehingga itu artinya signifikan 
karena kesalahan nya $0 \%$ dibawah ketentuan $5 \%$. Serta diketahui nilai RSquared 0.498454 variabel depresiasi rupiah mempengaruhi sebesar 49.84 $\%$ dan $50.16 \%$ dipengaruhi oleh faktor lain diluar model.

Tabel 6. Hasil Regresi Impor Bahan Baku

Dependent Variable: $Y$

Method: Least Squares

Date: 10/06/15 Time: 15:04

Sample: 2012M09 2015M07

Included observations: 35

\begin{tabular}{|c|c|c|c|c|}
\hline Variable & Coefficient & Std. Error & t-Statistic & Prob. \\
\hline $\begin{array}{l}C \\
x\end{array}$ & $\begin{array}{r}16827290 \\
-596.7917\end{array}$ & $\begin{array}{l}1190842 . \\
104.2098\end{array}$ & $\begin{array}{r}14.13058 \\
-5.726828\end{array}$ & $\begin{array}{l}0.0000 \\
0.0000\end{array}$ \\
\hline $\begin{array}{l}\text { R-squared } \\
\text { Adjusted R-squared } \\
\text { S.E. of regression } \\
\text { Sum squared resid } \\
\text { Log likelihood } \\
\text { F-statistic } \\
\text { Prob(F-statistic) }\end{array}$ & \multicolumn{3}{|c|}{$\begin{array}{l}\text { 0.498454 Mean dependent var } \\
0.483256 \text { S.D. dependent var } \\
772982.4 \text { Akaike info criterion } \\
\text { 1.97E+13 Schwarz criterion } \\
-523.1635 \text { Hannan-Quinn criter. } \\
\text { 32.79655 Durbin-Watson stat } \\
0.000002\end{array}$} & $\begin{array}{r}10048715 \\
1075305 \\
30.00935 \\
30.09822 \\
30.04003 \\
1.899196\end{array}$ \\
\hline
\end{tabular}

Dampak Depresiasi Rupiah Terhadap Perkembangan Nilai Impor Barang-barang Modal di Indonesia

Barang modal diklasifikasikan kedalam barang modal kecuali angkutan, mobil penumpang dan alat angkutan untuk industri. Berdasarkan hasil pengolahan data Bank indonesia, seperti tampak pada Tabel 3.4 tampak bahwa impor barang modal selama kurun waku September 2012 - Juli 2015 masih didominasi oleh impor barang modal kecuali untuk angkutan, yaitu sebesar $84.76 \%$ per tahun. Sedangkan $15.09 \%$ oleh alat angkutan untuk industri dan mobil penumpang. 
Tabel 7. Perkembangan Nilai Impor Barang Modal Indonesia Pada bulan September 2012 sampai dengan Juli 2015

\begin{tabular}{|c|c|c|c|c|c|c|}
\hline \multirow{3}{*}{ Bulan } & \multicolumn{6}{|c|}{ Impor Barang Modal } \\
\hline & \multicolumn{2}{|c|}{$\begin{array}{c}\text { Barang Modal (Kecuali } \\
\text { Angkutan) }\end{array}$} & \multicolumn{2}{|c|}{ Mobil Angkutan } & \multicolumn{2}{|c|}{ Angkkutan Lainnya } \\
\hline & Growth & Share & Growth & Share & Growth & Share \\
\hline 1 Sep 12 & & $78 \%$ & & $6 \%$ & & $16 \%$ \\
\hline 010 kt 2012 & $12 \%$ & $75 \%$ & $1 \%$ & $5 \%$ & $46 \%$ & $20 \%$ \\
\hline 1 Nov 12 & $-10 \%$ & $73 \%$ & $-12 \%$ & $5 \%$ & $1 \%$ & $22 \%$ \\
\hline 01 Des 12 & $3 \%$ & $72 \%$ & $-47 \%$ & $2 \%$ & $20 \%$ & $26 \%$ \\
\hline $01 \operatorname{Jan} 13$ & $0 \%$ & $82 \%$ & $33 \%$ & $4 \%$ & $-51 \%$ & $14 \%$ \\
\hline $01 \mathrm{Feb} 13$ & $-3 \%$ & $82 \%$ & $51 \%$ & $6 \%$ & $-16 \%$ & $12 \%$ \\
\hline $01 \mathrm{Mar} 13$ & $-4 \%$ & $80 \%$ & $-8 \%$ & $5 \%$ & $14 \%$ & $14 \%$ \\
\hline $1 \mathrm{Apr} 13$ & $4 \%$ & $80 \%$ & $-14 \%$ & $5 \%$ & $10 \%$ & $15 \%$ \\
\hline 01 Mei 13 & $3 \%$ & $80 \%$ & $-20 \%$ & $3 \%$ & $18 \%$ & $17 \%$ \\
\hline 01 Jun 13 & $-3 \%$ & $81 \%$ & $-5 \%$ & $3 \%$ & $-10 \%$ & $16 \%$ \\
\hline $01 \mathrm{Jul} 13$ & $22 \%$ & $85 \%$ & $32 \%$ & $4 \%$ & $-21 \%$ & $11 \%$ \\
\hline $01 \mathrm{Ag} 513$ & $-34 \%$ & $80 \%$ & $-16 \%$ & $5 \%$ & $-5 \%$ & $15 \%$ \\
\hline 1 Sep 13 & $29 \%$ & $82 \%$ & $-15 \%$ & $3 \%$ & $22 \%$ & $14 \%$ \\
\hline 01 Okt 13 & $-2 \%$ & $85 \%$ & $-4 \%$ & $3 \%$ & $-22 \%$ & $12 \%$ \\
\hline 1 Nov 13 & $6 \%$ & $89 \%$ & $-29 \%$ & $2 \%$ & $-29 \%$ & $8 \%$ \\
\hline 01 Des 13 & $-11 \%$ & $84 \%$ & $-24 \%$ & $2 \%$ & $61 \%$ & $14 \%$ \\
\hline 01 Jan 14 & $13 \%$ & $87 \%$ & $34 \%$ & $2 \%$ & $-18 \%$ & $11 \%$ \\
\hline $01 \mathrm{Feb} 14$ & $-13 \%$ & $86 \%$ & $55 \%$ & $4 \%$ & $-18 \%$ & $10 \%$ \\
\hline 01 Mar 14 & $-4 \%$ & $86 \%$ & $4 \%$ & $4 \%$ & $-5 \%$ & $10 \%$ \\
\hline 1 Apr 14 & $22 \%$ & $87 \%$ & $-31 \%$ & $2 \%$ & $22 \%$ & $10 \%$ \\
\hline 01 Mei 14 & $-11 \%$ & $78 \%$ & $-3 \%$ & $2 \%$ & $89 \%$ & $19 \%$ \\
\hline 01 Jun 14 & $8 \%$ & $86 \%$ & $19 \%$ & $3 \%$ & $-42 \%$ & $11 \%$ \\
\hline $01 \mathrm{Jul} 14$ & $-20 \%$ & $84 \%$ & $-20 \%$ & $3 \%$ & $-1 \%$ & $14 \%$ \\
\hline $01 \mathrm{Ag} 514$ & $24 \%$ & $89 \%$ & $6 \%$ & $3 \%$ & $-31 \%$ & $8 \%$ \\
\hline 1 Sep 14 & $3 \%$ & $87 \%$ & $14 \%$ & $3 \%$ & $32 \%$ & $10 \%$ \\
\hline $010 \mathrm{kt} 14$ & $5 \%$ & $89 \%$ & $-24 \%$ & $2 \%$ & $-5 \%$ & $9 \%$ \\
\hline 1 Nov 14 & $-13 \%$ & $92 \%$ & $-18 \%$ & $2 \%$ & $-47 \%$ & $6 \%$ \\
\hline 01 Des 14 & $-4 \%$ & $91 \%$ & $-26 \%$ & $2 \%$ & $16 \%$ & $7 \%$ \\
\hline $01 \operatorname{Jan} 15$ & $0 \%$ & $91 \%$ & $14 \%$ & $2 \%$ & $8 \%$ & $8 \%$ \\
\hline $01 \mathrm{Feb} 15$ & $-12 \%$ & $90 \%$ & $69 \%$ & $3 \%$ & $-22 \%$ & $7 \%$ \\
\hline 01 Mar 15 & $18 \%$ & $88 \%$ & $42 \%$ & $4 \%$ & $42 \%$ & $8 \%$ \\
\hline $1 \mathrm{Apr} 15$ & $-12 \%$ & $89 \%$ & $-39 \%$ & $3 \%$ & $-11 \%$ & $8 \%$ \\
\hline 01 Mei 15 & $0 \%$ & $92 \%$ & $-15 \%$ & $2 \%$ & $-39 \%$ & $5 \%$ \\
\hline 01 Jun 15 & $7 \%$ & $89 \%$ & $6 \%$ & $2 \%$ & $81 \%$ & $8 \%$ \\
\hline 01 jull 15 & $-21 \%$ & $91 \%$ & $-5 \%$ & $3 \%$ & $-48 \%$ & $6 \%$ \\
\hline
\end{tabular}

Sumber: Data diolah dari Bank Indonesia 
Jika dilihat dari nilai rata-rata pertumbuhan impor barang modal selama September 2012- Juli 2015 menunjukkan pertumbuhan sebesar $0.47 \%$ per tahun. Jika dilihat dari table 3.5 pertumbuhan impor barang modal mengalami fluktasi seperti pada barang impor alat angkutan untuk industri pada April 2014 - Mei 2014 mengalami peningkatan, sedangkan pada bulan Juni 2015 - Juli 2015 mengalami penurunan, penurunan ini terjadi sebagai dampak depresasi rupiah terhadap dollar,

Seperti halnya analisis sebelumnya, maka pada klasifikasi impor barang menurut modal pun dianalisis dengan menggunakan analisis kuadran. Analisis ini digunakan dalam rangka mengetahui hubungan antara pertumbuhan impor dengan share impor barang modal. Untuk menjelaskan analisis tersebut, maka digunakan scater diagram seperti tampak pada Gambar 6.

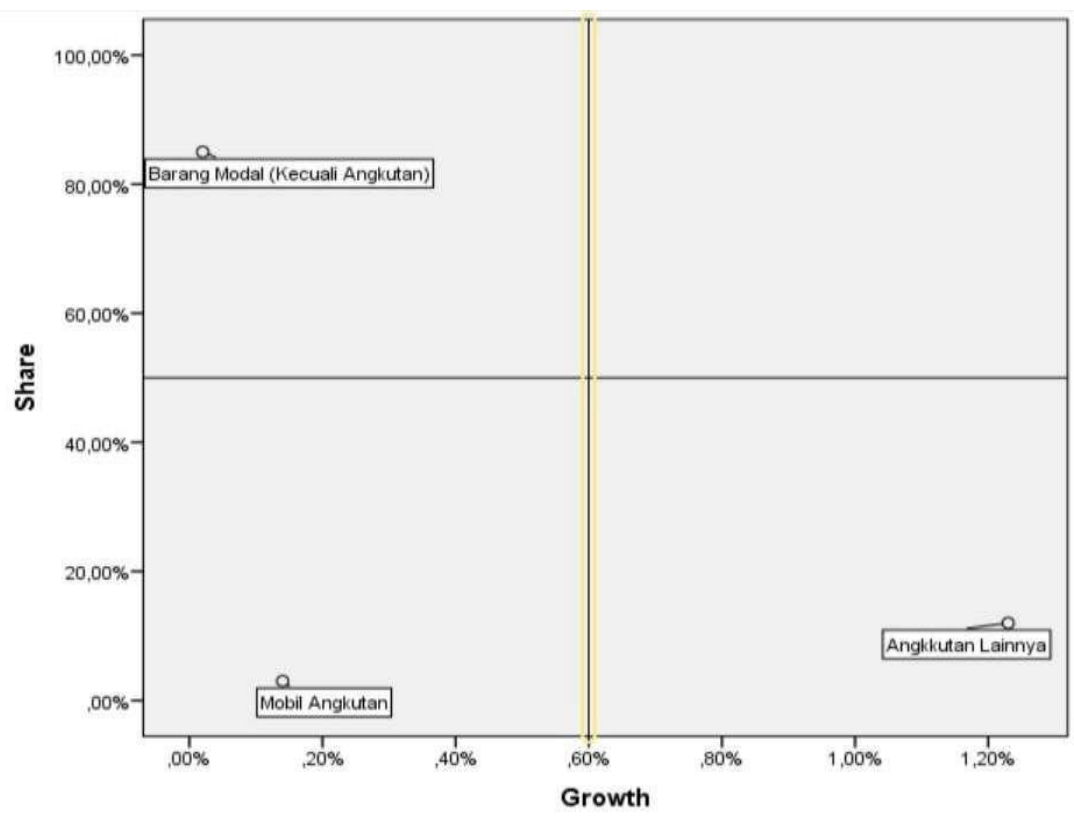

Gambar 6, Analisis Kuadran Impor Barang Modal

Sumber : Hasil Pengolahan Data

Berdasarkan Gambar 6 tampak bahwa Impor komoditas barang modal kecuali angkutan berada di kuadran dua yang menunjukan komoditas ini memiliki share yang tinggi atau di atas rata rata hal ini menunjukan komoditas ini memiliki kontribusi yang besar terhadap total impor barang 
modal Indonesia dan sisilain komoditas ini memiliki ketergantungan yang tinggi terhadap produk impor.

Berdasarkan laporan kementrian perdangangan nilai impor barang modal kecuali angkotan merupakan nilai impor terbesar dari komoditas impor barang modal lainya. Pada tahun 2014 nilai impor barang modal kecuali angkutan sebesar $25.661,8$ juta dollar meningkat dari tahun sebelum nya sebesar 26.128,2 juta dollar. Berbeda dengan nilai impor barang modal kecuali angkutan, komoditas impor mobil angkutan memiliki gwoth dan share yang rendah atau dibawah rata - rata itu ditunjukan posisi komoditas mobil angkutan berada pada kuadran tiga, hal ini juga menunjukan komditas ini memiliki ketergantungan yang rendah terhadap produk impor. Berdasarkan laporan kementrian perdangangan impor komoditas mobil angkutan mengalami penurunan dari tahun 2013 - 2014, pada tahun 2013 nilai impor nya sebesar 1.192,4 juta dollar sedangkan pada tahun 2014 sebesar 783,8 juta dollar.

Tabel 8. Hasil Regresi Impor Barang Modal

\begin{tabular}{|c|c|c|c|c|}
\hline \multicolumn{5}{|c|}{$\begin{array}{l}\text { Dependent Variable: I } \\
\text { Method: Least Squares } \\
\text { Date: } 10 / 07 / 15 \text { Time: } 14: 43 \\
\text { Sample: } 2012 \mathrm{M} 09 \text { 2015M07 } \\
\text { Included observations: } 35\end{array}$} \\
\hline Variable & Coefficient & Std. Error & t-Statistic & Prob. \\
\hline $\begin{array}{l}c \\
x\end{array}$ & $\begin{array}{r}4559191 . \\
-184.0246\end{array}$ & $\begin{array}{l}347503.8 \\
30.40983\end{array}$ & $\begin{array}{r}13.11983 \\
-6.051485\end{array}$ & $\begin{array}{l}0.0000 \\
0.0000\end{array}$ \\
\hline R-squared & \multicolumn{3}{|c|}{0.526001 Mean dependent var } & 2468973 \\
\hline Adjusted R-squared & 0.511638 & \multicolumn{2}{|c|}{ S.D. dependent var } & 322778.0 \\
\hline S.E. of regression & 225566.7 & \multicolumn{2}{|c|}{ Akaike info criterion } & 27.54606 \\
\hline Sum squared resid & $1.68 \mathrm{E}+12$ & \multicolumn{2}{|c|}{ Schwarz criterion } & 27.63494 \\
\hline Log likelihood & -480.0561 & \multirow{2}{*}{\multicolumn{2}{|c|}{ Hannan-Quinn criter. }} & 27.57674 \\
\hline F-statistic & 36.62047 & & & 2.052373 \\
\hline Prob(F-statistic) & 0.000001 & \multicolumn{2}{|c|}{ Durbin-Watson stat } & \\
\hline
\end{tabular}

Berdasarkan Tabel 8 menunjukkan adanya pengaruh depresiasi rupiah terhadap impor bahan modal itu tampak dari nilai thitung barang bahan 
modal (6.051485) > nilai t table (T kritis) 1.697 maka Ho ditolak atau Ha artinya variable signifikan. Dan diketahui dengan probabilitas (p) sebesar 0.0000 lebih kecil dari alfa $(\alpha)=5 \%$, sehingga itu artinya signifikan karena kesalahan nya $0 \%$ dibawah ketentuan $5 \%$. Serta diketahui nilai R-Squared 0.526001 variabel depresiasi rupiah mempengaruhi sebesar 52,60\% dan $47,40 \%$ dipengaruhi oleh faktor lain diluar model.

\section{SIMPULAN DAN SARAN}

Berdasarkan uraian pada bagian pembahasan, sebagai penutup kajian ini ditarik kesimpulan sebagai berikut:

1) Pekembangan impor Indonesia secara keseluruhan mengalami penurunan sebesar $0.84 \%$ selama September 2012 - Juli 2015. Jika ditinjau dari barang-barang menurut golongan ekonomi, perkembangan impor di Indonesia yang paling buruk adalah impor bahan baku. Hal ini tampak dari share masing-masing barang menunjukkan untuk bahan baku rata-rata sebesar 69,11\%, barang konsumsi sebesar $13,95 \%$, dan barang modal sebesar $16,94 \%$.

2) Selama kurun waktu September 2012 - Juli 2015 impor barang konsumsi di Indonesia didominasi oleh jenis barang angkutan bukan industri. Penurunan impor barang konsumsi yang paling besar adalah pada komoditas alat angkutan bukan industri yaitu sebesar $-52 \%$. Pada impor bahan baku secara keseluruhan mengalami penurunan. Penurunan yang paling dratis terjadi pada impor pelumas dan bahan bakar, penurunan tersebut sebesar 99\% pada bulan Juli 2015. Sedangkan pada impor barang modal didominasi oleh impor barang modal kecuali untuk angkutan, yaitu sebesar $84.76 \%$ per tahun. Pertumbuhan impor barang modal mengalami fluktasi seperti pada barang impor alat angkutan untuk industri pada April 2014 - Mei 2014 mengalami peningkatan, tetapi pada bulan Juni 2015 - Juli 2015 mengalami penurunan.

3) Depresiasi rupiah berpengaruh secara negative terhadap perkembangan barang-barang impor di Indonesia baik barang konsumsi, bahan baku dan penolong maupun barang-barang modal. Adapun besarnya pengaruh kurs terhadap permintaan impor secara keseluruhan sebesar 52,73 persen sedangkan sisanya sebesar 47,27 persen dipengaruhi oleh faktor yang lainnya yang tidak disebutkan 
dalam model seperti adanya penolakan L/C dari perbankan Indonesia oleh bank di luar negeri. Semakin tinggi nilai tukar rupiah terhadap dollar USA, maka semakin menurun permintaan barang-barang impor Indonesia.

\section{DAFTAR PUSTAKA}

Ayunia Pridayanti. 2015. Pengaruh Ekspor, Impor, dan Nilai Tukar Terhadap Pertumbuhan Ekonomi di Indonesia Periode 2002-2012. https://www.scribd. com/doc/226079960/pengaruh-ekspor-impordan-nilai-tukar-terhadap-pertumbuhan-ekonomi-di-Indonesiaperiode-2002-2012 [19 Oktober 2015]

Amir Machmud, 2001 "Dampak Depresiasi Rupiah Terhadap Perekonomian Indonesia", Penerbit STIE INABA Bandung. -2014. Potret Perekonomian Indonesia Pasca Orde Baru. Bandung: Spirit Muda Publishing House.

Badan Pusat Stastik. Statistik Indonesia, Bulan September 2012-Juli 2015

Bank Indonesia . Kurs Tahunan Indonesia Tahun 2000-2014. [Online]. Tersedia: www.bi.go.id

Batiz, Fransisco L. Rivara and Batiz, Luis A. Rivera. 1994. International Finance and open economy macroeconomics, Mac Millan Publishing, second edition.

Bulmer, Thomas, 1982. Input-Output Analysis in Developing Countries, John Wiley and Sons Lid.

Dumairy, 1997. Perekonomian Indonesia, Penerbit Erlangga, Jakarata.

Devi Abrista. Kontribusi Ekspor Impor Terhadap Pertumbuhan Ekonomi Di Indonesia

https://www.academia.edu/5769873/kontribusi_ekspor_impor_terha dap_pertumbuhan_ekonomi_di_Indonesia [19 Oktober 2015]

Grisvia Agustin 2009. “Analisa Paritas Daya Beli Pada Kurs Rupiah terhadap Dolar Amerika Serikat Periode September 1997-Desember 2007 dengan Menggunakan Metode Error Correction Model. Jurnal Ekonomi Studi Pembangunan, Volume 1 No. 1. Hal 27-38 Malang: Universitas Negeri Malang.

Husaini. 2010. Analisis Dampak Depresiasi Rupiah Terhadap Nilai Tukar Dagang (Term Of Trade) Dan Pertumbuhan Ekonomi Indonesia https://isa7695.wordpress.com ～/2010/07/19/analisis-dampak- 
depresiasi-nilai-rupiah-terhadap-nilai-tukar-dagang-term-of-tradedan-pertumbuhan-ekonomi-indonesia/ [8 Oktober 2015]

Kementerian Perindustrian Republik Indonesia (2015). Peran Sektor Industri Dalam Mendorong Pertumbuhan Ekonomi Nasional http://www.kemenperin.go.id /artikel/5422/Peran-Sektor-Industridalam-Mendorong-Pertumbuhan-Ekonomi-Nasional [12 Oktober 2015]

Kementerian Keuangan. 2013. Realisasi Investasi RI Kuartal IV 2013 Kembali Tembus Rp 100T. http://kemenkeu.go.id/Berita/realisasi-investasi-rikaurtal-iv-2013-kembali-tembus-rp100-t\# [1 Desember 2015]

Levi, D. Maurice, 1990. International Fianance, Mc Graw Hill.

Mankiw, N. Gregory, 2000. Macroeconomics. Alih Bahasa Imam Nurmawan. Edisi Keempat. Jakarta. Erlangga.

Paul R. Krugman, Maurice Obstfeld,1996. Ekonomic International, teori dan Kebijakan, PAU-FE-UI, Jakarta.

Tulus Tambunan, Krisis Ekonomi Indonesia (Penyebab dan Penanggulangannya), = LP3E-Kadin Indonesia, Jakarta,1998

--_---, 1998 Krisis Ekonomi dan Masa Depan Reformasi, LPFEE UI, Jakarta.

Sukirno, Sadono. 2011. Makroekonomi Teori Pengantar. PT Raja Grafindo Persada: Jakarta

Taufik Hidayat, 2013. Teori Dependensi https://www.academia.edu/8756509// Teori_Dependensi $\quad[16$ Desember 2015]

Triyono. 2008. "Analisis Perubahan Kurs Rupiah terhadap Dollar Amerika". Dalam Jurnal Ekonomi Pembangunan, Volume 9 No. 2. Hal 156-167 Surakarta: Universitas Muhammadiyah Surakarta.

Zulhanafi,dkk. 2013. Analisis Faktor-Faktor Yang Mempengaruhi Produktivitas Dan Tingkat Pengangguran Di Indonesia.Jurnal Ekonomi Vol II.No.003 Tahun 2013 